\section{Students on the Move:} The Future of International

\section{Students in the United States}

\section{Dao luu, Olga Bain, and Madeleine Green}

Dao Luu is a project associate at the American Council on Education. Address: 1 Dupont Circle, Washington, DC 20036, USA. E-mail: Dao_luu@ace.nche.edu. Olga Bain is assistant professorial lecturer at the George Washington University. E-mail: ob_olga@usa.net. Madeleine Green is vice president for international initiatives at the American Council on Education. E-mail: madeleine_green@ace.nche.edu.

$\mathrm{T}$ he American Council on Education released an issue brief, Students on the Move: The Future of International Students in the United States, in October 2006, that summarizes the existing research on international students in the Unites States and examines the US market position with respect to other major hosting countries in attracting international students. It found that while the United States continues to enroll the majority of international students, trends in other major hosting and sending countries suggests that US dominance cannot be taken for granted.

The discussion of global trends in international student enrollments assumes an agreement on the definition of an international student. However, because countries count international students differently, international comparisons are potentially inconsistent. Some countries include permanent residents or other long-time residents when reporting international student enrollments; other countries do not. Some count only students enrolled in degree-earning programs; others adopt broader parameters to include students in intensive English-language programs. Definitions vary not only among countries but also change over time within the same country, which makes yearly comparisons among countries more difficult. The impact of these discrepancies in data reporting is difficult to estimate. UNESCO recently introduced the term and definition for an internationally mobile student in an attempt to address these inconsistencies. It remains to be seen whether countries will adopt this term and change their data reporting. Nonetheless, the available data provide valuable information on the mobility of international students and where they are choosing to pursue their studies.

\section{Trends in Other Countries}

In 2004, there were 2.5 million international students worldwide; it is projected that this will increase to 7.2 million in 2025. According to OECD data, in 2004 the United States attracted 2I.6 percent of all the international students, down from 25.3 percent in 2000 . While the US share of international student enrollments slipped, other major host countries maintained or expanded their enrollments. Among the top competitor countries, the United Kingdom was the only country to report a decline in market share (I percentage point), whereas France expanded its share by 2 percentage points and the other countries remained stable. Outside of the top six hosting countries, Canada, New Zealand, and South Africa also expanded their market share.

Among the top six host countries, the United States had the weakest growth in international student enrollments, from I999/2000 to 2004/05. While international student enrollments grew by nearly I7 percent in the United States, they grew by 29 percent in the United Kingdom, 46 percent in Germany, 8I percent in France, 42 percent in Australia, and Io8 percent in Japan. However, the absolute numbers in these countries are considerably smaller. Growth rates in competitor countries may be attributed to national policies, initiatives to recruit international students, coordination between governments and their universities, and in some cases a strong institutional motivation to generate revenue. The United States is also a mature market; thus, it may be more difficult to significantly expand enrollments there.

International student enrollments in the United States

In 2004, there were 2.5 million international students worldwide; it is projected that this will increase to 7.2 million in 2025.

could also be affected by efforts of China and India to expand their higher education capacity. Both China and India are developing graduate programs to encourage more of their own students to study at home and reduce the outflow of money and talent. Strategic investments in Ioo Chinese universities are aimed at improving their quality and turning them into "world-class" institutions in research and innovation. India is also strengthening its higher education system. Furthermore, traditional source countries are now also host countries. The Chinese Ministry of Education reported that international student enrollments grew by 213 percent from 44,7II in I999 to I40,000 in 2005. In the past five years, international student enrollments have increased in China by more than 20 percent annually.

\section{Strategies in Other Countries}

Governments have developed national systems that coordinate the recruitment of international students and promote their respective higher education brand worldwide. Examples include Australia Education International, Edufrance, the British Council, and the German Academic Exchange Service. In the United Kingdom, the prime minister's Initiative for International Education combines institutional and national efforts to recruit international students. Some governments have also adopted national policies that lessen restrictions on 
international students including flexible work/study options, allowing part-time employment while studying, and permitting international students to stay longer after graduation to find employment.

Immigration and other policies have been strategically aligned to attract international students. Canada, for example, expects that recent immigration policy changes and the easing of employment restrictions for international students will increase enrollments from abroad by as much as 20,000 . Other policies include a point-based immigration system that is favorable to highly skilled professionals (as found in the United Kingdom) or the granting of permanent residency to professionals in designated high-demand fields of engineering, computer sciences, and hard sciences (as practiced in Germany).

Non-English-speaking countries are increasingly offering programs in English to appeal to international students. For example, the Netherlands, Sweden, Finland, Poland, Turkey, and Japan offer from 50 to more than I,000 programs in English. In Korea there are Io English-only universities.

A strategy that can potentially be very successful is the creation of regional education hubs. In 1999, Singapore announced that it would attract "world-class" academic institutions to become the regional destination of choice for students, researchers, and industry. The Middle East is home to two emerging educational hubs-Knowledge Village in Dubai (United Arab Emirates) and Education City in Doha (Qatar)both of which are establishing themselves as hosts of various foreign education providers and training centers.

Non-English-speaking countries are increasingly offering programs in English to appeal to international students.

\section{ConClusion}

The United States continues to receive the largest number of international students. However, recent trends indicate that the global landscape is changing. Although potential demand is high, a redistribution of international students among host countries is under way. This change may be due to perceptions that the United States is unwelcoming, vigorous competition from other countries, and successful national strategies of other countries to recruit international students.

Author's note. This article is based on "Students on the Move: The Future of International Students in the United States," by Olga Bain, Dao Luu, and Madeleine Green, available at the ACE Web site: http://www.acenet.edu.

\section{Demographic Challenges and the Future of the Higher Education}

\section{Manja Klemencic and Jochen Fried}

Manja Klemencic is a postdoctoral fellow at the Minda de Gunzburg Center for European Studies at Harvard University, Cambridge, MA, USA. E-mail: m.klemencic.01@cantab.net. Jochen Fried is director of education initiatives at the Salzburg Seminar, Salzburg, Austria. E-mail: jfried@salzburgseminar.org.

$\prod$ he demographic prospects certainly add a new dimension to the familiar pressures on higher education. It is surprising then that these factors are so rarely addressed in relevant scholarly literature or in the higher education policy arena. The aim of this special section of International Higher Education (IHE) is to highlight demography in higher education planning and to encourage further research on this theme. The articles in this special section of IHE result from presentations at the Salzburg Seminar session, Shifting Demographics in Higher Education, conducted in November 2006.

Higher education is rapidly becoming a universal aspiration. Over the past decades, the number of students has been increasing steadily across the world, and according to some projections the student number will almost double to reach I60 million by 2025 . This trend, however, will play out in very dissimilar ways given the diverging demographic developments in different parts of the world. Studies predict that until 2020 and beyond in most of the developed world, especially in Europe, populations will decline rapidly, while in developing countries, especially in Asia and Africa, the number of people will continue to grow. At the same time, life expectancy is also undergoing dramatic changes, rising continuously where countries prosper, but remaining stagnant or even decreasing where countries are falling behind.

These demographic trends have far-reaching implications for higher education. In regions where the anticipated increase in population is matched by the prospect of an overall improvement of socioeconomic conditions, as in Asia, the rising demand for higher education will accelerate. By comparison, the declining birthrates in Europe combined with a stable socioeconomic situation may result in an excess supply of higher education in terms of domestic demand. While some regions will struggle to provide education, especially quality education, for all eligible individuals, others will engage in an ever fiercer "battle for brainpower," as described in an article in the Economist (October 6, 2006). The new knowledge society requires a steady turnout of an increasingly highly qualified workforce as well as a substantial pool of competent knowledge producers. To be able to accomplish these tasks, any high- 